Asian Australas. J. Biosci. Biotechnol. 2020, 5 (1), 6-14

Asian-Australasian Journal of

Bioscience and Biotechnology

ISSN 2414-1283 (Print) 2414-6293 (Online)

www.ebupress.com/journal/aajbb

\title{
Article \\ Water management effects on irrigation cutback and yield performance of dry direct seeded boro rice
}

\author{
Md. Moshiur Rahman*, Md. Mehedi Masood and Md. Abdur Rahman Sarkar \\ Department of Agronomy, Bangladesh Agricultural University, Mymensingh, Bangladesh
}

${ }^{*}$ Corresponding author: Professor Dr. Md. Moshiur Rahman, Department of Agronomy, Bangladesh Agricultural University, Mymensingh, Bangladesh. E-mail: rahmanag63@gmail.com

Received: 02 March 2020/Accepted: 18 April 2020/ Published: 30 April 2020

\begin{abstract}
Dry direct seeding is an alternative rice production method that reduces $50-60 \%$ irrigation water required compared to the conventional method. The present study was undertaken with a view to optimize irrigation requirement for dry direct seeded rice. The experiment involved seven water management levels and two rice varieties in a split-plot design allocating water management levels in main plot and rice variety in subplot. The treatments were replicated thrice. The water management levels are (i) puddled transplanted rice with full irrigation (PTR-CI), (ii) puddled transplanted rice with alternate wetting and drying (AWD) irrigation (PTRAWD), (iii) dry direct seeded rice with no standing water at all, (iv) dry direct seeding with AWD irrigation (DDSR-AWD), (v) dry direct seeded rice with $3-5 \mathrm{~cm}$ standing water from panicle initiation to heading, (vi) dry direct seeded rice with $3-5 \mathrm{~cm}$ standing water from panicle initiation to grain filling, (vii) dry direct seeded rice with $3-5 \mathrm{~cm}$ standing water from heading to grain filling. Two rice varieties included in the experiments are BRRI dhan 28 and BRRI dhan29. The frequency and amount of irrigation for different plots were recorded. Data on different crop characters, yield and related attributes were collected and were subjected to statistical analysis using a computer package program MSTAT-C. The results reveal that rice gave the highest grain yield in dry direct seeding system where the standing water was maintained from panicle initiation stage to flowering (T5) or grain filling stage (T6) at reproductive phase. The T5 treatment required 7-9 irrigations whereas T6 required 9-12 irrigations. The treatment T5 required 50\% less irrigation water than PTR-CI method. Thus, it may be concluded that dry direct seeded rice should be practiced for rice and standing water should be maintained from panicle initiation to heading for obtaining higher grain yield with least irrigation input.
\end{abstract}

Keywords: water scarcity; alternate wetting and drying; saturation; puddle transplanted rice; dry direct seeded rice

\section{Introduction}

Transplanting of seedling on puddled soil followed by conventional flood irrigation is the principal system of rice culture. This system requires 1000-2000 mm irrigation water of which about 20-40 per cent goes for puddling (Bhuiyan et al., 1995). Farmers of Bangladesh generally keep standing water in the rice field after transplanting for easy weed control and crop establishment. Rice cultivation in boro (winter) season using this traditional puddle transplanted system is being subjected to uncertainty due to shortage of irrigation water both from surface and underground sources. Puddling destroys the soil structure and adversely affects crop productivity. Dry direct seeding is an alternative rice establishment system which facilitates rice cultivation with 50-60\% less irrigation water (Rahman et al., 2013; Rahman and Masood, 2014). The water demand in rice culture is reduced in the dry direct seeding system by avoiding puddling and also by reducing the losses due to evaporation, leaching, percolation (Bouman and Tuong, 2001). The dry direct seeding is cost effective and gives more profit, reduces the adverse effect on soil quality, methane emissions and arsenic accumulation (Rahman, 2019). In dry direct seeded system, rice seed is sown in dry cultivated land and generally soil is kept at aerobic 
conditions from sowing to panicle initiation stage (vegetative phase). Thus, rice plants acquire higher tolerance to water deficit under dry direct seeded system than the conventional system. The crop under dry direct seeded system mostly relies on residual soil moisture and requires no standing water during the vegetative phase. Generally, $2-5 \mathrm{~cm}$ standing water is maintained in the dry direct seeded rice field from panicle initiation to grain filling stage (reproductive phase) as being practiced in the conventional puddle transplanted system, even when alternate wetting and drying is practiced. This is because of the fact that rice yield usually declines when soil dries below saturation during reproductive phase (Bouman and Tuong, 2001). Dry direct seeding is a new system of rice culture and research reports related to scheduling of keeping standing water in rice field especially during the reproductive phase is highly scarce. The present study was therefore, undertaken to optimize time and duration of maintaining standing water during the reproductive phase for maximizing yield of dry direct seeded boro rice.

\section{Materials and Methods}

\subsection{Site and soil}

The experiment was conducted at the Agronomy Field Laboratory of Bangladesh Agricultural University (BAU), Mymensingh $\left(24^{\circ} 43^{\prime} 8.3^{\prime \prime} \mathrm{N}\right.$ latitude, $90^{\circ} 25^{\prime} 41.2^{\prime \prime} \mathrm{E}$ longitude, 18 altitude) during boro season (JanuaryJune) of 2011 and 2012 to study the yield response of dry direct seeded rice to different levels of irrigation regime. The site is a well-drained medium low land belonging to Non-calcareous Dark Grey soil under the Old Brahmaputra Floodplain Agro-ecological Zone (AEZ-9).The pH of soil was 6.85 and the soil contained 1.50\% organic matter, $0.074 \%$ total nitrogen, $11.85 \mathrm{ppm}$ phosphorus, $0.18 \%$ potassium, $9.5 \mathrm{ppm}$ sulphur and $0.43 \mathrm{ppm}$ zinc. During the period from January to March only 20.3 and $45.7 \mathrm{~mm}$ rainfall occurred in 2011 and 2012, respectively. The average maximum temperatures were 28.97 and $28.17{ }^{\circ} \mathrm{C}$ in 2011 and 2012, and minimum temperatures were 18.03 and $22.89{ }^{\circ} \mathrm{C}$, respectively. The relative humidity during the January to March was $78.80-80.15 \%$.

\subsection{Experimental design and layout}

The two factor experiment consisted of seven water management levels in main plots and two rice varieties (BRRI Dhan28 and BRRI Dhan29) in sub-plot. The trial was laid out in a split-plot design with three replications. The water management levels comprised (i) puddled transplanted rice with full irrigation, (ii) puddled transplanted rice with alternate wetting and drying irrigation (AWD), (iii) dry direct seeded rice (no standing water at all), (iv) dry direct seeded rice with AWD irrigation, (v) dry direct seeded rice with $5 \mathrm{~cm}$ standing water from panicle initiation to heading, (vi) dry direct seeded rice with $5 \mathrm{~cm}$ standing water from panicle initiation to grain filling, (vii) dry direct seeded rice with $5 \mathrm{~cm}$ standing water from heading to grain filling.

\subsection{Crop management}

Rice seeds were sown on 05 January 2011 and 01 January 2012 at $25 \mathrm{~cm}$ x $15 \mathrm{~cm}$ spacing allocating $4-5$ seeds hill $^{-1}$ (finally 3 seedlings retained) in dry direct seeded system while for puddled transplanted system 30-day old seedlings were transplanted on 04 February 2011 and 29 January 2012, respectively at $25 \mathrm{~cm} \mathrm{x} 15 \mathrm{~cm}$ spacing allocating 3 seedlings hill ${ }^{-1}$. During land preparation, well decomposed cowdung was applied @ $5 \mathrm{t} \mathrm{ha}^{-1}$. The land was fertilized with N, P, K, S and Zn @ 120, 14, 58, 8 and $1 \mathrm{~kg} \mathrm{ha}^{-1}$ in the form of urea, triple supper phosphate (TSP), muriate of potash (MOP), gypsum and zinc sulphate, respectively. All other fertilizers and $1 / 4$ urea were applied at final land preparation. Rest $3 / 4$ urea was applied in three equal splits at 30, 45 and 60 days after seeding (DAS) for DSR and at 15, 35 and 55 days after transplanting (DAT) for puddle transplanted ones. Three and four hand weeding were done for conventional puddle transplanted rice and dry direct seeded plots, respectively. The experiment plots were carefully observed regularly and different agronomic practices were done properly when necessary.

\subsection{Irrigation and water management}

During land preparation no irrigation was required in dry direct seeding (DSR) system while two irrigations were applied in puddle transplanted system.. The conventional irrigated plots were kept continuously flooded until grain filling. Perforated plastic pipe (AWD pipe/magic pipe) was set up in each plot for AWD irrigation. The AWD plots were kept continuously flooded up to 15 days after transplanting, and then AWD irrigation was practiced where next irrigations were applied when water disappeared in the pipe to 15 below the soil surface. In case of DDS plots, a light irrigation was required to keep the soil at field capacity from sowing till 45 DAS. The plots were bounded by earthen bunds with plastic lining to a depth of $0.5 \mathrm{~m}$ to minimize lateral movement of 
water into and through the bunds. There was a $1.5 \mathrm{~m}$ wide buffer between all sub-plots. Free flood irrigation was used and the amount and frequency of irrigation for different systems were recorded. The volume of irrigation water applied to each plot at each event was measured by volumetric method.

\subsection{Data recording}

At maturity, the crop was harvested and threshed manually. Grain yield was determined from central $3.15 \mathrm{~m}^{2}(2.1 \mathrm{~m}$ $\times 1.5 \mathrm{~m}$ ) area of each plot. The moisture percent of sun dried grain and straw were determined by oven dry method. Finally, grain yields were adjusted to $14 \%$ moisture content. The straw was sun dried and weighed the yields of grain and straw were converted to $\mathrm{t} \mathrm{ha}^{-1}$. Panicle density was determined from the harvest area where from the tiller density was determined. The number of filled florets (grains) and unfilled florets per panicle were determined from 10 randomly selected panicles for each plot. Floret fertility was calculated as percentage of filled grain to the total number of floret per panicle. Average grain weight was determined from the weight of 1000 grains from the threshed grain sample for each plot and expressed at $14 \%$ moisture content. Data on plant height, number of tiller hill ${ }^{-1}$ and number of grain panicle ${ }^{-1}$ were recorded from the randomly selected five hills per plot.

\subsection{Data analysis}

The collected data for yield and related parameters were compiled and subjected to statistical analysis following Analysis of Variance (ANOVA) technique with the help of a computer based package programme MSTAT-C. The differences among the treatment means were adjudged by Duncan's Multiple Range Test.

\section{Results}

\subsection{Irrigation requirement}

Puddle transplanted full irrigated (PTR-CI) rice required 15-16 and 17-18 irrigations for BRRI dhan28 and BRRI dhan29, respectively. The amounts of water applied for BRRI dhan28 were 1190 and $1185 \mathrm{~mm}$ (Table 1) and for BRRI dhan29 were 1250 and $1230 \mathrm{~mm}$ (Table 2) in 2011 and 2012, respectively. The puddle transplanted alternate wetting and drying irrigation (PTR-AWD) plots required 150 to $275 \mathrm{~mm}$ less irrigation compared to the PTR-CI. The dry direct seeded rice plots with no standing water from sowing to harvesting (T3) required 510-525 mm water for BRRI dhan28 and 600-620 mm water for BRRI dhan29. The dry directed seeded rice field maintaining standing water from panicle initiation till grain filling (T6) required $660-700 \mathrm{~mm}$ water for BRRI dhan 28 and 730-740 mm water for BRRI dhan29. It was found that the dry direct seeded plots with standing water from panicle initiation (PI) to heading stage required $598 \mathrm{~mm}$ irrigation. On the other hand, the puddle transplanted full irrigation (PTR-CI) and puddle transplanted alternate wetting and drying irrigation (PTR-AWD) required 1214 and $983 \mathrm{~mm}$ water, respectively. The plot where rice was grown under puddle transplanted AWD system the irrigation water saving was $20-23 \%$ for BRRI dhan28 (Table 1) while that was only $12 \%$ for BRRI dhan 29 (Table 2). Across different water management for dry direct seeded BRRI dhan 28 the highest water saving was found with T3, which was 52-56\% in BRRI dhan28 and 50\% in BRRI dhan29. The lowest water saving was found with T6, which was $41-42 \%$ in BRRI dhan 28 while that was $40 \%$ for BRRI dhan29. It was also noted that use of alternate wetting and drying (AWD) irrigation for puddle transplanted (PTR-AWD) and dry direct seeded (DDS-AWD) rice required $12-23 \%$ and $50-56 \%$ less irrigation than the puddle transplanted full irrigation (PTR-CI) treatment. Thus, the water saving for DDS rice is three fold higher than puddle transplanted alternate wetting drying irrigated rice.

\subsection{Grain yield and related attributes}

Plant height, number of tillers $\mathrm{m}^{-2}$, number of panicle $\mathrm{m}^{-2}$, panicle length, number of grains panicle ${ }^{-1}, 1000$-grain weight, grain yield and straw yield were affected significantly by water management options, variety and their interactions both in 2011 and 2012. The plant height differed due to water management treatments and the highest value was found with T5 in 2011 while that was highest with T6 in 2012. The shortest plants $(90.58 \mathrm{~cm}$ in 2011 and $101.3 \mathrm{~cm}$ in 2012) were obtained from T3 in both the growing seasons (Table 3). It was noted that between the two varieties, BRRI dhan 28 produced taller plants. It was noted that number of tiller $\mathrm{m}^{-2}$ was also unaffected for interaction between cultivar and water management only in 2012. It was noted that number of tiller $\mathrm{m}^{-2}$ was also unaffected for interaction between cultivar and water management only in 2012. It was also noted that between the two varieties, BRRI dhan28 produced higher 1000-grain weight than BRRI dhan 29 while reverse occurred for the other characters. The total number of tillers $\mathrm{m}^{-2}$ was found the highest with T5 in both the years although this value was statistically similar to those of T3, T4 and T7. The lowest values for total tillers $\mathrm{m}^{-2}$ was found with $\mathrm{T} 1$ which is similar to that of $\mathrm{T} 2$ in both the growing seasons. The number of panicle $\mathrm{m}^{-2}$ 
was the highest (371.5 and 370.6) for T5 which was similar to that for T4 (Table 3). The length of panicle was tallest with T6 $(24.83 \mathrm{~cm}$ and $24.95 \mathrm{~cm})$ while the short panicle was found with T1 $(23.33 \mathrm{~cm}$ and $22.32 \mathrm{~cm})$. The number of grains panicle $^{-1}$ was the highest with T2 (99.33 and 104.0) as shown in Table 4. The highest 1000-grain weight was found in T1 (23.32 and 23.73g) which were statistically at par with T2 and T4 in 2011 and similar with T2, T4, T5 and T6, respectively in 2012. Grain yield was highest with T6 which were $7.32 \mathrm{t} \mathrm{ha}^{-1}$ in 2010-2011 and $7.53 \mathrm{t} \mathrm{ha}^{-1}$ in 2012 (Table 4). The statistically similar higher yield in 2011 was found with T5 ( $7.26 \mathrm{t}$ ha) while in 2012 the similar highest yield was found with T4 $\left(7.35 \mathrm{tha}^{-1}\right)$ and T6 $\left(7.43 \mathrm{tha}^{-1}\right)$. The highest straw yield was recorded with T6 $\left(8.48 \mathrm{tha}^{-1}\right.$ in 2011 and $9.34 \mathrm{tha}^{-1}$ in 2012). Treatment T5 and T4 produced the highest yield. The lowest straw yield was noted with $\mathrm{T} 3\left(6.69 \mathrm{t} \mathrm{ha}^{-1}\right.$ in $2010-11$ and $7.55 \mathrm{t} \mathrm{ha}^{-1}$ in 2011-2012) as shown in Table 4.

The interaction effect of water management option and variety showed the tallest for BRRI dhan28 with T5 in 2011 while that was tallest for BRRI dhan 28 with T4 in 2012. The highest number of tillers $\mathrm{m}^{-2}$ was found with BRRI dhan 29 under T5 treatment (446.33) in 2011 while the parameter remained unaffected during the following season (Table 5). The number of panicles $\mathrm{m}^{-2}$ was highest with BRRI dhan29 with T5 (409 and 397 in 2011 and 2012, respectively). The number of grains panicle ${ }^{-1}$ was the highest with BRRI dhan 29 with T2 (103.33) in 2011 while with T6 (106.67) in 2012 (Table 6). The grain weight was highest with BRRI dhan 28 for T1 in both the years. Grain yield was highest with BRRI dhan29 for T6 $\left(7.65\right.$ and $\left.7.63 \mathrm{t} \mathrm{ha}^{-1}\right)$ in both the seasons (Table 6). Straw yield attained highest with BRRI dhan29 for T5 $\left(8.78 \mathrm{tha}^{-1}\right)$ in 2011 while the highest $\left(9.55 \mathrm{tha}^{-1}\right)$ was found with BRRI dhan28 for T5 $\left(9.55 \mathrm{tha}^{-1}\right)$ in 2012 (Table 6).

Table 1. Effect of different water management on irrigation requirement and frequency of application for a winter rice variety BRRI dhan28 in 2011 and 2012.

\begin{tabular}{|c|c|c|c|c|c|c|}
\hline \multirow[t]{2}{*}{ Water management options } & \multicolumn{2}{|c|}{2011} & \multirow{2}{*}{$\begin{array}{l}\text { \% water } \\
\text { saving } \\
\text { over PTR- } \\
\text { CI }\end{array}$} & \multicolumn{2}{|c|}{2012} & \multirow{2}{*}{$\begin{array}{l}\text { \% water } \\
\text { saving over } \\
\text { PTR-CI }\end{array}$} \\
\hline & $\begin{array}{l}\text { Amount } \\
(\mathrm{mm})\end{array}$ & $\begin{array}{l}\text { Frequency } \\
\text { (No.) }\end{array}$ & & $\begin{array}{l}\text { Amount } \\
(\mathrm{mm})\end{array}$ & $\begin{array}{l}\text { Frequency } \\
\text { (No.) }\end{array}$ & \\
\hline $\mathrm{T}_{1}=$ puddled transplanted rice with full irrigation (PTR-CI) & 1190 & 16 & - & 1185 & 15 & - \\
\hline $\begin{array}{l}\mathrm{T}_{2}=\text { puddled transplanted rice with alternate wetting and drying } \\
\text { irrigation (PTR-AWD) }\end{array}$ & 940 & 13 & 20.0 & 910 & 12 & 23.2 \\
\hline $\mathrm{T}_{3}=$ dry direct seeded rice with no standing water at all & 510 & 7 & 52.0 & 525 & 8 & 55.7 \\
\hline $\begin{array}{l}T_{4}=\text { dry direct seeded rice following AWD irrigation (DDSR- } \\
\text { AWD) }\end{array}$ & 530 & 7 & 48.0 & 540 & 9 & 54.4 \\
\hline $\begin{array}{l}\mathrm{T}_{5}=\text { dry direct seeded rice with standing water from panicle } \\
\text { initiation to heading }\end{array}$ & 540 & 7 & 49.6 & 550 & 8 & 53.6 \\
\hline $\begin{array}{l}\mathrm{T}_{6}=\text { dry direct seeded rice with standing water from panicle } \\
\text { initiation to grain filling }\end{array}$ & 660 & 9 & 41.6 & 700 & 11 & 40.9 \\
\hline $\begin{array}{l}\mathrm{T}_{7}=\text { dry direct seeded rice with standing water from heading to } \\
\text { grain filling }\end{array}$ & 530 & 7 & 49.6 & 610 & 7 & 48.6 \\
\hline
\end{tabular}

\begin{tabular}{|c|c|c|c|c|c|c|}
\hline \multirow[t]{2}{*}{ Water management options } & \multicolumn{2}{|c|}{2011} & \multirow{2}{*}{$\begin{array}{l}\text { \% water } \\
\text { saving over } \\
\text { PTR-CI }\end{array}$} & \multicolumn{2}{|c|}{2012} & \multirow{2}{*}{$\begin{array}{l}\text { \% water } \\
\text { saving over } \\
\text { PTR-CI }\end{array}$} \\
\hline & $\begin{array}{l}\text { Amount } \\
(\mathrm{mm})\end{array}$ & $\begin{array}{l}\text { Frequency } \\
\text { (No.) }\end{array}$ & & $\begin{array}{l}\text { Amount } \\
(\mathrm{mm})\end{array}$ & $\begin{array}{l}\text { Frequency } \\
\text { (No.) }\end{array}$ & \\
\hline $\mathrm{T}_{1}=$ puddled transplanted rice with full irrigation (PTR-CI) & 1250 & 18 & - & 1230 & 17 & - \\
\hline $\begin{array}{l}\mathrm{T}_{2}=\text { puddled transplanted rice with alternate wetting and } \\
\text { drying irrigation (PTR-AWD) }\end{array}$ & 1000 & 15 & 12.2 & 1080 & 14 & 12.2 \\
\hline$T_{3}=$ dry direct seeded rice with no standing water at all & 600 & 9 & 49.6 & 620 & 10 & 49.6 \\
\hline $\begin{array}{l}T_{4}=\text { dry direct seeded rice following AWD irrigation (DDSR- } \\
\text { AWD) }\end{array}$ & 650 & 10 & 45.5 & 670 & 11 & 45.3 \\
\hline $\begin{array}{l}T_{5}=\text { dry direct seeded rice with standing water from panicle } \\
\text { initiation to heading }\end{array}$ & 630 & 8 & 49.6 & 620 & 9 & 49.6 \\
\hline $\begin{array}{l}\mathrm{T}_{6}=\text { dry direct seeded rice with standing water from panicle } \\
\text { initiation to grain filling }\end{array}$ & 730 & 10 & 39.8 & 740 & 12 & 39.8 \\
\hline $\begin{array}{l}\mathrm{T}_{7}=\text { dry direct seeded rice with standing water from heading to } \\
\text { grain filling }\end{array}$ & 630 & 8 & 48.0 & 640 & 8 & 48.0 \\
\hline
\end{tabular}


Table 3. Effect of water management options and variety on growth and yield attributes of winter rice under dry direct seeded system of cultivation in 2010-11 and 2011-12 seasons.

\begin{tabular}{|c|c|c|c|c|c|c|}
\hline \multirow{2}{*}{ Treatment } & \multicolumn{2}{|c|}{ Plant height $(\mathbf{c m})$} & \multicolumn{2}{|c|}{ Number of tillers $\mathbf{m}^{-2}$} & \multicolumn{2}{|c|}{ Number of panicle $\mathrm{m}^{-2}$} \\
\hline & 2010-11 & 2011-12 & 2010-11 & 2011-12 & 2010-11 & 2011-12 \\
\hline \multicolumn{7}{|c|}{ Water Management } \\
\hline $\mathrm{T}_{1}$ & $94.75 \mathrm{c}$ & $109.2 \mathrm{bc}$ & $343.16 \mathrm{c}$ & $349.0 \mathrm{c}$ & $319.66 \mathrm{~cd}$ & $326.0 \mathrm{c}$ \\
\hline $\mathrm{T}_{2}$ & $95.08 \mathrm{c}$ & $107.8 \mathrm{c}$ & $348.66 \mathrm{c}$ & $359.3 \mathrm{c}$ & $313.83 d$ & $313.3 \mathrm{~d}$ \\
\hline $\mathrm{T}_{3}$ & $90.58 \mathrm{e}$ & $101.3 \mathrm{~d}$ & $405.00 \mathrm{a}$ & $395.3 \mathrm{a}$ & $323.16 \mathrm{~cd}$ & $316.8 \mathrm{~d}$ \\
\hline $\mathrm{T}_{4}$ & $99.08 \mathrm{ab}$ & $108.7 \mathrm{c}$ & $392.16 \mathrm{a}$ & $402.3 \mathrm{a}$ & $356.50 \mathrm{ab}$ & $362.1 \mathrm{ab}$ \\
\hline $\mathrm{T}_{5}$ & $99.33 \mathrm{a}$ & $110.2 \mathrm{~b}$ & $411.83 \mathrm{a}$ & $410.0 \mathrm{a}$ & $371.50 \mathrm{a}$ & $370.6 \mathrm{a}$ \\
\hline $\mathrm{T}_{6}$ & $97.83 \mathrm{~b}$ & $112.2 \mathrm{a}$ & $369.16 b$ & $383.5 \mathrm{~b}$ & $343.00 \mathrm{bc}$ & $358.0 \mathrm{~b}$ \\
\hline $\mathrm{T}_{7}$ & $92.83 \mathrm{~d}$ & $107.5 \mathrm{c}$ & $402.33 \mathrm{a}$ & $394.0 \mathrm{a}$ & $335.83 \mathrm{bcd}$ & $340.0 \mathrm{bc}$ \\
\hline Level of sig. & $* * *$ & ** & $* * *$ & $* * *$ & $* * *$ & ** \\
\hline $\mathrm{CV} \%$ & 2.98 & 3.01 & 2.56 & 0.022 & 3.34 & 1.91 \\
\hline \multicolumn{7}{|l|}{ Variety } \\
\hline $\mathrm{V}_{1}$ & $97.21 \mathrm{a}$ & $110.33 \mathrm{a}$ & $357.81 \mathrm{~b}$ & $356.76 \mathrm{~b}$ & $315.76 \mathrm{~b}$ & $321.24 \mathrm{~b}$ \\
\hline $\mathrm{V}_{2}$ & $94.07 \mathrm{~b}$ & $105.91 \mathrm{~b}$ & $405.71 \mathrm{a}$ & $407.10 \mathrm{a}$ & $359.52 \mathrm{a}$ & $360.76 \mathrm{a}$ \\
\hline Level of sig. & $* * *$ & ** & $* * *$ & $* * *$ & $* * *$ & $* * *$ \\
\hline $\mathrm{CV} \%$ & 2.98 & 3.01 & 2.56 & 2.2 & 3.34 & 1.91 \\
\hline
\end{tabular}

Table 4. Effect of water management options, variety and their interaction on yield and yield attributes of boro rice under dry direct seeded system of cultivation in 2009-10 and 2010-11 seasons.

\begin{tabular}{|c|c|c|c|c|c|c|c|c|}
\hline \multirow{2}{*}{ Treatment } & \multicolumn{2}{|c|}{ Filled grain panicle ${ }^{-1}$} & \multicolumn{2}{|c|}{1000 grain wt. (g) } & \multicolumn{2}{|c|}{ Grain yield $\left(\right.$ tha $\left.^{-1}\right)$} & \multicolumn{2}{|c|}{ Straw yield $\left(\right.$ tha $\left.^{-1}\right)$} \\
\hline & 2010-11 & 2011-12 & 2010-11 & 2011-12 & 2010-11 & 2011-12 & 2010-11 & 2011-12 \\
\hline \multicolumn{9}{|c|}{ Water management } \\
\hline $\mathrm{T}_{1}$ & $96.33 \mathrm{ab}$ & $102.1 \mathrm{ab}$ & $23.32 \mathrm{a}$ & $23.73 a$ & $6.51 \mathrm{~d}$ & $6.88 \mathrm{bc}$ & $7.52 \mathrm{c}$ & $8.51 b c$ \\
\hline $\mathrm{T}_{2}$ & $99.33 \mathrm{a}$ & $104.0 \mathrm{a}$ & $22.93 \mathrm{ab}$ & $23.4 \mathrm{ab}$ & $6.63 \mathrm{~cd}$ & $7.07 \mathrm{~b}$ & $7.86 \mathrm{bc}$ & $8.74 \mathrm{~b}$ \\
\hline $\mathrm{T}_{3}$ & $76.66 \mathrm{e}$ & $70.8 \mathrm{~d}$ & $21.68 \mathrm{~d}$ & $22.23 \mathrm{c}$ & $5.40 \mathrm{e}$ & $5.53 \mathrm{~d}$ & $6.69 \mathrm{~d}$ & $7.55 \mathrm{~d}$ \\
\hline $\mathrm{T}_{4}$ & $93.16 b c$ & $101.0 \mathrm{ab}$ & $22.75 \mathrm{abc}$ & $23.03 \mathrm{ab}$ & $6.95 b c$ & $7.35 \mathrm{ab}$ & $8.05 \mathrm{ab}$ & $9.13 \mathrm{ab}$ \\
\hline $\mathrm{T}_{5}$ & $90.50 \mathrm{c}$ & $99.1 \mathrm{~b}$ & $22.61 b c$ & $23.01 \mathrm{ab}$ & $7.26 \mathrm{ab}$ & $7.43 \mathrm{ab}$ & $8.37 \mathrm{a}$ & $9.22 \mathrm{a}$ \\
\hline $\mathrm{T}_{6}$ & $93.33 b c$ & $103.3 \mathrm{a}$ & $22.6 b c$ & $23.1 \mathrm{ab}$ & $7.32 \mathrm{a}$ & $7.53 \mathrm{a}$ & $8.48 \mathrm{a}$ & $9.34 \mathrm{a}$ \\
\hline $\mathrm{T}_{7}$ & $81.66 \mathrm{~d}$ & $80.3 \mathrm{c}$ & $22.00 \mathrm{c}$ & $22.25 b c$ & $5.68 \mathrm{e}$ & $6.17 \mathrm{c}$ & $7.00 \mathrm{~cd}$ & $7.92 \mathrm{c}$ \\
\hline Level of sig. & $* * *$ & $* * *$ & $*$ & $* *$ & $* * *$ & $* * *$ & $* * *$ & $* * *$ \\
\hline $\mathrm{CV} \%$ & 4.4 & 5.12 & 1.67 & 1.98 & 3.92 & 3.68 & 4.33 & 3.77 \\
\hline \multicolumn{9}{|l|}{ Variety } \\
\hline $\mathrm{V}_{1}$ & $86.00 \mathrm{~b}$ & $92.10 \mathrm{~b}$ & $23.83 a$ & $24.37 \mathrm{a}$ & $6.24 \mathrm{~b}$ & $6.65 \mathrm{~b}$ & $7.33 \mathrm{~b}$ & 8.61 \\
\hline $\mathrm{V}_{2}$ & $94.28 \mathrm{a}$ & $97.29 \mathrm{a}$ & $21.59 \mathrm{~b}$ & $21.58 \mathrm{~b}$ & $6.83 \mathrm{a}$ & $7.06 \mathrm{a}$ & $7.86 \mathrm{a}$ & 8.66 \\
\hline Level of sig. & $* * *$ & *** & $* * *$ & $* * *$ & $* * *$ & $* * *$ & $* * *$ & NS \\
\hline $\mathrm{CV} \%$ & 4.4 & 5.12 & 1.67 & 1.98 & 3.92 & 3.68 & 4.33 & 3.77 \\
\hline
\end{tabular}

In a column, with the same letter(s) or without letter(s) do not differ significantly whereas figures with dissimilar letter differ significantly (as per DMRT) at 5\% level of probability; NS $=$ Not significant, $*=$ Significant at $5 \%$ level of probability, $* *=$ Significant at $1 \%$ level of probability, $* * *=$ Significant at $0.1 \%$ level, $\mathrm{T}_{1}=$ puddled transplanted rice with full irrigation (PTR-CI), $T_{2}=$ puddled transplanted rice with alternate wetting and drying irrigation (PTR-AWD), $\mathrm{T}_{3}=$ dry direct seeded rice with no standing water at all, $\mathrm{T}_{4}=$ dry direct seeded rice following AWD irrigation (DDSR-AWD), $\mathrm{T}_{5}=$ dry direct seeded rice with standing water from panicle initiation to heading, $\mathrm{T}_{6}=$ dry direct seeded rice with standing water from panicle initiation to grain filling and $\mathrm{T}_{7}=$ dry direct seeded rice with standing water from heading to grain filling, $\mathrm{V}_{1}=\mathrm{BRRI}$ dhan $28, \mathrm{~V}_{2}=\mathrm{BRRI}$ dhan 29 . 
Table 5. Effect of water management options, variety and their interaction on growth parameters of dry direct seeded boro rice in 2011 and 2012.

\begin{tabular}{|c|c|c|c|c|c|c|}
\hline \multirow{2}{*}{$\begin{array}{l}\text { Variety } \times \\
\text { management options }\end{array}$} & \multicolumn{2}{|c|}{ Plant height (cm) } & \multicolumn{2}{|c|}{ Number of tillers $\mathbf{m}^{-2}$} & \multicolumn{2}{|c|}{ Number of panicle $\mathbf{m}^{-2}$} \\
\hline & 2011 & 2012 & 2011 & 2012 & 2011 & 2012 \\
\hline $\mathrm{V}_{1} \mathrm{~T}_{1}$ & $96.16 \mathrm{bc}$ & $114.0 \mathrm{a}$ & $315.66 \mathrm{~g}$ & 323.6 & $295.33 \mathrm{~h}$ & $302.6 \mathrm{~d}$ \\
\hline $\mathrm{V}_{1} \mathrm{~T}_{2}$ & $96.66 \mathrm{bc}$ & $111.3 b$ & $321.33 \mathrm{fg}$ & 329.3 & $300.00 \mathrm{gh}$ & $294.3 \mathrm{e}$ \\
\hline $\mathrm{V}_{1} \mathrm{~T}_{3}$ & $91.16 \mathrm{fg}$ & 103.6de & $395.00 \mathrm{~d}$ & 365.0 & $311.00 \mathrm{fgh}$ & 299.3de \\
\hline $\mathrm{V}_{1} \mathrm{~T}_{4}$ & $101.00 \mathrm{a}$ & $114.3 \mathrm{a}$ & $364.66 \mathrm{e}$ & 376.6 & 325.00def & $333.3 \mathrm{c}$ \\
\hline $\mathrm{V}_{1} \mathrm{~T}_{5}$ & $101.66 \mathrm{a}$ & $113.3 \mathrm{a}$ & $377.33 \mathrm{e}$ & 389.3 & $334.00 \mathrm{de}$ & $343.6 \mathrm{bc}$ \\
\hline $\mathrm{V}_{1} \mathrm{~T}_{6}$ & 100.66a & $111.3 b$ & $334.00 \mathrm{f}$ & 356.6 & 318.00efg & $337.0 \mathrm{bc}$ \\
\hline $\mathrm{V}_{1} \mathrm{~T}_{7}$ & $93.16 \mathrm{e}$ & $104.3 \mathrm{~d}$ & $396.66 \mathrm{~cd}$ & 376.6 & $327.00 \mathrm{def}$ & $338.3 \mathrm{bc}$ \\
\hline $\mathrm{V}_{2} \mathrm{~T}_{1}$ & 93.33de & $104.3 \mathrm{~d}$ & $370.66 \mathrm{e}$ & 374.3 & $344.00 \mathrm{~d}$ & $349.3 b$ \\
\hline $\mathrm{V}_{2} \mathrm{~T}_{2}$ & $93.50 \mathrm{de}$ & $104.3 d$ & $376.00 \mathrm{e}$ & 369.3 & 327.66def & $332.3 \mathrm{c}$ \\
\hline $\mathrm{V}_{2} \mathrm{~T}_{3}$ & $90.00 \mathrm{~g}$ & $99.0 \mathrm{e}$ & $415.00 \mathrm{bc}$ & 425.6 & $335.33 \mathrm{de}$ & $334.3 \mathrm{c}$ \\
\hline $\mathrm{V}_{2} \mathrm{~T}_{4}$ & $97.16 \mathrm{~b}$ & 103.0de & $419.66 \mathrm{~b}$ & 428.0 & $388.00 \mathrm{~b}$ & $391.0 \mathrm{ab}$ \\
\hline $\mathrm{V}_{2} \mathrm{~T}_{5}$ & $97.00 \mathrm{~b}$ & $107.0 \mathrm{c}$ & $446.33 a$ & 430.6 & $409.00 \mathrm{a}$ & $397.6 \mathrm{a}$ \\
\hline $\mathrm{V}_{2} \mathrm{~T}_{6}$ & $95.00 \mathrm{~cd}$ & $113.0 \mathrm{a}$ & $404.33 \mathrm{bcd}$ & 410.3 & $368.00 \mathrm{c}$ & $379.0 \mathrm{ab}$ \\
\hline $\mathrm{V}_{2} \mathrm{~T}_{7}$ & 92.50ef & $110.6 \mathrm{bc}$ & $408.00 \mathrm{bcd}$ & 411.3 & $344.66 \mathrm{~d}$ & $341.6 \mathrm{bc}$ \\
\hline Level of sig. & $* * *$ & $* *$ & $* * *$ & NS & $* * *$ & $* *$ \\
\hline CV\% & 2.98 & 3.01 & 2.56 & 2.20 & 3.34 & 1.91 \\
\hline
\end{tabular}

Table 6. Effect of water management options, variety and their interaction on yield and yield attributes of dry direct seeded boro rice in 2011 and 2012.

\begin{tabular}{|c|c|c|c|c|c|c|c|c|}
\hline \multirow{2}{*}{$\begin{array}{l}\text { Variety } \quad \times \\
\text { Water } \\
\text { management } \\
\text { options }\end{array}$} & \multicolumn{2}{|c|}{ Filled grain panicle $^{-1}$} & \multicolumn{2}{|c|}{1000 grain wt. (g) } & \multicolumn{2}{|c|}{ Grain yield (tha ${ }^{-1}$ ) } & \multicolumn{2}{|c|}{ Straw yield $\left(\right.$ tha $\left.^{-1}\right)$} \\
\hline & 2011 & 2012 & 2011 & 2012 & 2011 & 2012 & 2011 & 2012 \\
\hline $\mathrm{V}_{1} \mathrm{~T}_{1}$ & $91.33 \mathrm{~cd}$ & $105.67 \mathrm{ab}$ & $24.26 \mathrm{a}$ & $25.10 \mathrm{a}$ & $6.13 \mathrm{e}$ & $6.55 \mathrm{~cd}$ & $7.07 \mathrm{ef}$ & $8.42 b c$ \\
\hline $\mathrm{V}_{1} \mathrm{~T}_{2}$ & $95.33 \mathrm{bcd}$ & $102.67 \mathrm{bc}$ & $23.76 \mathrm{ab}$ & $24.63 \mathrm{ab}$ & $6.35 \mathrm{de}$ & $6.91 \mathrm{c}$ & $7.58 \mathrm{de}$ & $8.89 \mathrm{~b}$ \\
\hline $\mathrm{V}_{1} \mathrm{~T}_{3}$ & $70.66 \mathrm{f}$ & $71.33 \mathrm{ef}$ & $23.30 \mathrm{~b}$ & $23.93 \mathrm{~b}$ & $5.16 \mathrm{~h}$ & $5.41 \mathrm{e}$ & $6.62 \mathrm{fg}$ & $7.42 \mathrm{~cd}$ \\
\hline $\mathrm{V}_{1} \mathrm{~T}_{4}$ & $91.00 \mathrm{~cd}$ & $95.00 \mathrm{~cd}$ & $24.00 \mathrm{ab}$ & $24.23 \mathrm{ab}$ & $6.78 \mathrm{~cd}$ & $7.17 \mathrm{bc}$ & $7.85 \mathrm{~cd}$ & $9.21 \mathrm{ab}$ \\
\hline $\mathrm{V}_{1} \mathrm{~T}_{5}$ & $88.00 \mathrm{de}$ & $95.33 \mathrm{~cd}$ & $23.93 \mathrm{ab}$ & $24.83 \mathrm{ab}$ & $6.98 \mathrm{c}$ & $7.30 \mathrm{bc}$ & $7.96 \mathrm{bcd}$ & $9.41 \mathrm{a}$ \\
\hline $\mathrm{V}_{1} \mathrm{~T}_{6}$ & $90.00 \mathrm{cde}$ & $100.00 \mathrm{bcd}$ & $23.83 \mathrm{ab}$ & $24.76 \mathrm{ab}$ & $7.00 \mathrm{c}$ & $7.43 b$ & $8.06 \mathrm{bcd}$ & $9.55 \mathrm{a}$ \\
\hline $\mathrm{V}_{1} \mathrm{~T}_{7}$ & $75.66 \mathrm{f}$ & $74.67 \mathrm{e}$ & $23.33 b$ & $23.06 \mathrm{bc}$ & $5.28 \mathrm{gh}$ & $5.73 \mathrm{de}$ & $6.16 \mathrm{~g}$ & $7.40 \mathrm{~d}$ \\
\hline $\mathrm{V}_{2} \mathrm{~T}_{1}$ & $101.33 \mathrm{ab}$ & $106.67 \mathrm{a}$ & $22.38 \mathrm{c}$ & $22.36 \mathrm{~cd}$ & $6.89 \mathrm{c}$ & $7.21 b c$ & $7.96 \mathrm{bcd}$ & $8.61 b c$ \\
\hline $\mathrm{V}_{2} \mathrm{~T}_{2}$ & $103.33 \mathrm{a}$ & $105.33 \mathrm{ab}$ & $22.10 \mathrm{~cd}$ & $22.16 \mathrm{~cd}$ & $6.91 \mathrm{c}$ & $7.23 b c$ & $8.15 \mathrm{bcd}$ & $8.60 \mathrm{bc}$ \\
\hline $\mathrm{V}_{2} \mathrm{~T}_{3}$ & $82.66 \mathrm{e}$ & $70.33 \mathrm{f}$ & $21.66 \mathrm{cde}$ & $20.60 \mathrm{f}$ & $5.65 \mathrm{fg}$ & $5.65 \mathrm{de}$ & $6.76 \mathrm{fg}$ & $7.69 \mathrm{c}$ \\
\hline $\mathrm{V}_{2} \mathrm{~T}_{4}$ & $95.33 \mathrm{bcd}$ & $103.00 \mathrm{~b}$ & $21.50 \mathrm{de}$ & $21.83 \mathrm{de}$ & $7.11 \mathrm{bc}$ & 7.53ab & $8.26 \mathrm{abc}$ & $9.05 \mathrm{ab}$ \\
\hline $\mathrm{V}_{2} \mathrm{~T}_{5}$ & $93.00 \mathrm{~cd}$ & $103.00 \mathrm{~b}$ & $20.23 \mathrm{f}$ & $21.20 \mathrm{ef}$ & $7.55 \mathrm{ab}$ & 7.56ab & $8.78 \mathrm{a}$ & $9.04 \mathrm{ab}$ \\
\hline $\mathrm{V}_{2} \mathrm{~T}_{6}$ & $96.66 \mathrm{abc}$ & $106.67 \mathrm{a}$ & $21.37 \mathrm{e}$ & $21.44 \mathrm{ef}$ & $7.65 \mathrm{a}$ & $7.63 a$ & $8.5 \mathrm{ab}$ & $9.15 \mathrm{ab}$ \\
\hline $\mathrm{V}_{2} \mathrm{~T}_{7}$ & 87.66de & $86.00 \mathrm{de}$ & $21.93 \mathrm{cde}$ & $21.43 \mathrm{ef}$ & $6.08 \mathrm{ef}$ & $6.61 \mathrm{~cd}$ & $6.6 \mathrm{fg}$ & $8.45 b c$ \\
\hline Level of sig. & $* * *$ & $* *$ & $* *$ & $*$ & $*$ & $*$ & $*$ & $* *$ \\
\hline CV\% & 4.40 & 5.12 & 1.67 & 1.98 & 3.92 & 3.68 & 4.33 & 3.77 \\
\hline
\end{tabular}

In a column, with the same letter(s) or without letter(s) do not differ significantly whereas figures with dissimilar letter differ significantly (as per DMRT) at 5\% level of probability; NS = Not significant, $*=$ Significant at $5 \%$ level of probability, $* *=$ Significant at $1 \%$ level of probability, $* * *=$ Significant at $0.1 \%$ level, $\mathrm{T}_{1}=$ puddled transplanted rice with full irrigation (PTR-CI), $\mathrm{T}_{2}=$ puddled transplanted rice with alternate wetting and drying irrigation $(\mathrm{PTR}-\mathrm{AWD}), \mathrm{T}_{3}=\mathrm{dry}$ direct seeded rice with no standing water at all, $\mathrm{T}_{4}=$ dry direct seeded rice following $\mathrm{AWD}$ irrigation $(\mathrm{DDSR}-\mathrm{AWD}), \mathrm{T}_{5}=$ dry direct seeded rice with standing water from panicle initiation to heading, $\mathrm{T}_{6}=$ dry direct seeded rice with standing water from panicle initiation to grain filling and $\mathrm{T}_{7}=$ dry direct seeded rice with standing water from heading to grain filling, $\mathrm{V}_{1}=\mathrm{BRRI}$ dhan28, $\mathrm{V}_{2}=\mathrm{BRRI}$ dhan29.

\section{Discussion}

Rice cultivation in boro (winter) season is fully reliant on irrigation as rainfall during this season is scanty. Puddle transplanting with full irrigation is the common practice in rice culture which requires huge irrigation 
water. The extraction of groundwater for irrigation in winter rice leads to ground water table decline making the rice culture unsustainable. In the present study, puddle transplanted rice with full irrigation (T1) required 1250$1230 \mathrm{~mm}$ irrigation water. It was found that puddle transplanted rice with AWD irrigation (T2) saved 12-23\% irrigation water while dry direct seeded rice with no standing water during the whole crop period (T3) saved 52$58 \%$ irrigation compared with T1. Further, the water saving was $45-54 \%$ when AWD approach is used along with dry direct seeded system (T4). The present study supports the previous reports in that the AWD irrigation in puddle transplanted rice can save 20-25\% irrigation water while the dry direct seeding method can save 50$70 \%$ compared to the puddle transplanted full irrigated rice (Rahman et al., 2013). It was also noted in the present study that the water saving was more for variety BRRI dhan28 than variety BRRI dhan29. It was simply because of longer field duration of BRRI dhan29.

In the present study BRRI dhan29 gave higher yield than BRRI dhan28. The higher yield in BRRI dhan29 was mainly attributed to the production of higher number of tillers and panicles per unit area, longer panicle and higher number of filled grain panicle ${ }^{-1}$ than BRRI dhan28. The similar result was reported by Rahman et al. (2019) who found that BRRI dhan29 was higher yielder than BRRI dhan28. In the present study, the higher yield of BRRI dhan 29 was attributed to production of higher number of number of panicle $\mathrm{m}^{-1}$ and number of grains panicle. The greater yield contributed by BRRI dhan29 was mainly due to number of panicle $\mathrm{m}^{-1}$ and number of grains panicle. Previous study suggested that rice yield has strong positive relation with number of effective tiller production (Ameen et al., 2014).

In respect to the grain yield, the lowest yield was found with dry direct seeded rice with no standing water at all (T3). This grain yield reduction might be related to the production of shortest panicle, smallest grain, lowest filled grain and higher unfilled grain in this treatment. It was further observed that DDS-AWD system with standing water from panicle initiation to grain filling (T4) gave the highest grain and straw yield. This water management practice gave 8.5 to $11 \%$ higher grain yield than the puddle transplanted full irrigated rice (T1 treatment) while this treatment gave $26 \%$ higher yield than DDS with no standing water at all (T3 treatment). The lowest yield from the plots receiving no standing water during the whole crop period of dry direct seeded system (T3) mainly due to water stress during the panicle initiation (Gupta et al., 2006; Kumar et al., 2009). Like grain yield, the limited supply of irrigation water in this treatment also resulted in decreased straw yield (Kato et al., 2006). The plot which was provided withstanding water from heading to grain filling (T7) showed grain yield similar to that of the plots having no standing water at all (T3 treatment). On the other hand, the puddle transplanted AWD plot (T2) also gave significantly lower yield than dry direct seeded AWD plots (T4). The present study showed that the dry direct seeded field gave higher yield and saved 50-60\% irrigation water compared with the puddle transplanted full irrigated plots. Thus, the results of the present study indicated that dry direct seeded rice field not only saves water but also can produce higher yield than puddle transplanted AWD rice.

Dry direct seeded rice produced taller plants than puddle transplanted rice. Among the dry direct seeded rice, irrigation using AWD approach (T4) produced the tallest plants while the shortest plant was found in dry direct seeded rice with no standing water at all (T3). The saturated soil may have increased access to greater amount of nutrients and the plants also absorb more oxygen and solar radiation resulting in taller plants production (van der Hoek et al., 2001; Abu-Khalifa, 2010). In our experiment puddled transplanted rice with full irrigation (PTR-CI) gave lower yield than dry direct seeded rice with standing water for a certain period during reproductive phase. Numerous studies focusing on this aspect revealed that continuous standing water of rice during cultivation is not essential for obtaining high yields rather, maintaining a very thin water layer, at saturated soil condition, or alternate wetting and drying can reduce water applied to the field by about 40-70 percent compared with the traditional practice of continuous shallow submergence, without a significant yield loss (Tabbal et al., 1992; Singh et al., 1996).

The higher number of tillers $\mathrm{m}^{-2}$ and panicle $\mathrm{m}^{-2}$ in dry direct seeded rice with standing water from panicle initiation to heading contributed to higher yield than puddled transplanted rice with full irrigation. Maximum tillers from DDS rice may be due to larger and massive root system which provided access to a greater amount of nutrients from the soil and also plants absorb more oxygen and solar radiation resulting in higher production of tillers. In addition, lack of transplanting injury in dry direct seeding system contributed to higher tiller production (Horie, 2004; Gill et al., 2006; Kabir, 2007; IRRI, 1988; Dingkuhn et al., 1990). Production of higher percentage of filled grains is the key to higher yields under non-flooded (aerobic) conditions (Bouman $e t$ al., 2006). Increased number of filled and unfilled grain panicle ${ }^{-1}$ was observer in dry direct seeded rice (no standing water at all) while the number increased with irrigation treatments. The potential number of filled grains per panicle has been essentially established by the number of fertilized flowers (kernels). The number of filled grains per panicle is primarily determined by conditions and events during this stage since only flowers 
fertilized can become filled grains. Water deficiency at anthesis period and early grain filling stage might be the reason of lowest number of filled grain and highest number of unfilled grain panicle ${ }^{-1}$ for this treatment. Rice is very susceptible to water stress in the period around flowering, since reduced water availability causes spikelet sterility (Lu et al. 2001; Wopereis et al. 1996; Cruz et al. 1986; Ekanayake et al. 1989). Boonjung and Fukai (1996) reported that drought stress at filling grains period decreases the grain filling duration. Thousand grain weight of rice under DDS method with standing water during reproductive phase is higher than that for no standing water at reproductive phase. This might be weak development of grain due to water deficiency. Patel (2000) stated that water regimes had significant effect on 1000 grains weight of rice. Thus, avoiding water stress and keeping the soil wet during panicle initiation and grain filling could help yield improvement in dry direct seeded rice.

\section{Conclusions}

The present study reveals that both BRRI dhan28 and BRRI dhan29 varieties gave highest grain yield in dry direct seeding system when standing was maintained from panicle initiation to heading at reproductive phase. This water management practice required 550 and $620 \mathrm{~mm}$ irrigation with 7-8 and 8-9 irrigations respectively. This practice saved 50\% irrigation water and gave 8.8 and $9.9 \%$ higher yield in BRRI dhan28 and BRRI dhan 29 , respectively compared with conventional puddle transplanted method. Thus, it may be concluded that dry direct seeded rice should be practiced for rice and standing water should be maintained from panicle initiation to heading for obtaining higher grain yield with least irrigation input.

\section{Acknowledgements}

We thank the Program for Agriculture and Life Science (PALS) of Bangladesh Academy of Sciences (BAS) and the United States Department of Agriculture (USDA) for providing fund for this research under the project CR\# 21.

\section{Conflict of interest}

None to declare.

\section{References}

Abu-Khalifa AA, 2010. Response of some rice varieties to irrigation withholding under different sowing dates. Agric. and Biol. J., 1: 56-64.

Ameen A, Z Aslam, QU Zaman, Ehsanullah, SI Zamir, I Khan and MJ Subhani, 2014. Performance of Different Cultivars in Direct Seeded Rice (Oryza sativa L.) with Various Seeding Densities. American J. Plant Sci., 5: 3119-3128.

Bhuiyan S, M Sattar and M Khan, 1995. Improving water use efficiency in rice irrigation through wet-seeding. Irrigation Sci., 16: 1-8.

Boonjung H and S Fukai, 1996. Effect of soil water deficit at different growth stages on rice growth and yield under upland conditions. Field Crops Res., 48: 47-55.

Bouman BA, Y Xiaoguang, W Huaqi, W Zhimin, Z Junfang and C Bin, 2006. Performance of aerobic rice varieties under irrigated conditions in North China. IRRI, Metro Manila, Philippines. Field Crops Res., 97: 53-65.

Bouman BAM and TP Tuong, 2001. Field Water management to save water and its productivity in irrigated rice. Agric. and Water Managmt., 49: 11-30.

Bouman BAM and TP Tuong, 2001. Field Water management to save water and its productivity in irrigated rice. Agric. and Water Managmt., 49: 11-30.

Cruz RT, JC O'Toole, M Dingkuhn, EG Yambao, M Thangaraj and SK De Datta, 1986. Shoot and root responses to water deficits in rainfed lowland rice. Aust. J. Plant Physiol., 13: 567-575.

Dingkuhn M, HF Schnier, SK De Datta, K Dorffling and C Javellana, 1990. Nitrogen fertilization of directseeded flooded vs. transplanted rice. II. Interactions among canopy properties. Crop Sci., 30: 1284-1292.

Ekanayake IJ, SK De Datta and PL Steponkus, 1989. Spikelet sterility and flowering response of rice to water stress at anthesis. Ann. Bot., 63: 257-264

Gill MS, Kumar P and Kumar A, 2006. Growth and yield of direct-seeded rice (Oryza sativa) as influenced by seeding technique and seed rate under irrigated conditions. Indian Journal of Agronomy, 51: 283-287.

Gupta RK, JK Ladha, S Singh, R Singh, ML Jat, Y Saharawat, VP Singh, SS Singh, G Singh, G Sah, M Gathala and RK Sharma, 2006. Production Technology for Direct Seeded Rice. Technical Bulletin Series 8.In "RiceWheat Consortium for the Indo-Gangetic Plains, New Delhi, India," 14 pp. 
Horie T, 2004. Can yields of lowland rice resume the increases that they showed in the 1980s? New directions for a diverse planet: Proceedings of the $4^{\text {th }}$ International Crop Science Congress. Brisbane, Australia, 26Sep.[http://www.cropscience.org.au/icsc.2004/symposia/2/4/1869_horiet.htm].

IRRI (International Rice Research Institute), 1988. Annual Report for 1987. IRRI,Los Banes, Laguna, Philippines. pp. 271-389.

Kabir MH, 2007. Effects of crop establishment method, nitrogen fertilization and weed management on the productivity of Boro rice under high and low land ecosystems. PhD. Dissertation, Department of Agronomy, Bangladesh Agricultural University, Mymensingh. pp. 42-225.

Kato Y, A Kamoshita, J Yamagishi and J Abe, 2006. Growth of three rice (Oryza sativa L.) cultivars under upland conditions with different levels of water supply 1 . Nitrogen content and dry matter production. Plant Production Sci., 9: 422-434.

Kumar V, JK Ladha and MK Gathala, 2009. Direct drill-seeded rice: a need of the day. In: Annual Meeting of Agronomy Society of America, November 1-5, Pittsburgh, America.

Lu J, T Hirasawa and J Lu, 2001. Study on intermittent irrigation for paddy rice. Water use efficiency. Pedosphere, 11: 49-56.

Patel JR, 2000. Effect of water regimes, variety and blue-green algae on rice (Oryza sativa). Indian J. Agron., 45: 103-106.

Rahman MM and MM Masood, 2014. Sustaining productivity of boro (winter) season using minimal water through dry direct seeding of rice. J. Crop and Weed, 10: 24-30.

Rahman MM, MM Masood and MAR Sarkar, 2019. Effect of seed rate on yield performance of dry direct seeded winter rice. Fundament. and Appl. Agric., 4: 642-648.

Rahman MM, MAR Sarkar, MM Masood, MJ Uddin and MJ Ali, 2013. Dry Direct Seeded Rice Production Technology. Department of Agronomy, Bangladesh Agricultural University, Mymensingh. pp. 1-44.

Rahman, MM, 2019. Potential benefits of dry direct seeded rice culture: A review. Fundament. and Appl. Agric., 4: 1-15.

Singh CB, TS Aujla, BS Sandhu and KI Khera, 1996. Effects of transplanting data and irrigation regime on growth, yield and water use in rice (Oryza sativa) in northern India. Indian J. Agric. Sci., 66: 137-141.

Tabbal DF, RM Lampayan and SI Bhuiyan, 1992. "Water-efficient irrigation technique for rice. In V. V. N. Murty, \& K. Koga (Eds.), Soil and water engineering for paddy field management" Proceedings of the International Workshop on Soil and Water Engineering for Paddy Field Management, 28-30 January Bangkok, Thailand: Asian Institute of Technology.

Van der Hoek W, R Sakthivadivel, M Renshaw, JB Silver, MH Birley and Konradsen, 2001. Alternate wet/dry in rice cultivation: A practical way to save water and control malaria and Japanese encepthalitis? Research Report 47. Colombo, Sri Lanka: International Water Management Institute.

Wopereis MCS, MJ Kropff, AR Maligaya and TP Tuong, 1996. Drought-stress responses of two lowland rice cultivars to soil water status. Field Crops Res., 46: 21-39. 